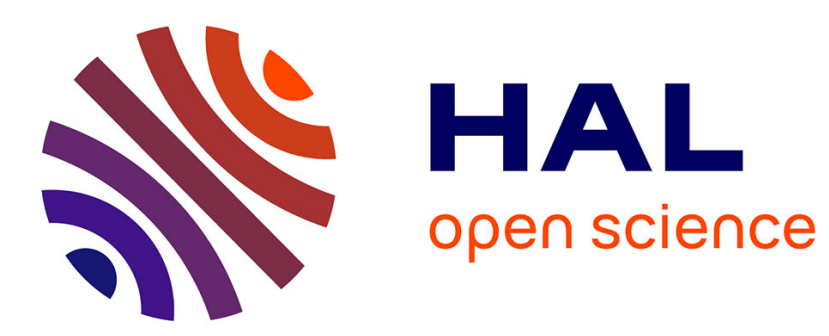

\title{
The resource curse literature as seen through the appropriability lens: a critical survey
}

\author{
Mehrdad Vahabi
}

\section{To cite this version:}

Mehrdad Vahabi. The resource curse literature as seen through the appropriability lens: a critical survey. Public Choice, 2018, 175 (3-4), pp.393-428. 10.1007/s11127-018-0533-5 . hal-02242454

\section{HAL Id: hal-02242454 \\ https://hal.science/hal-02242454}

Submitted on 1 Aug 2019

HAL is a multi-disciplinary open access archive for the deposit and dissemination of scientific research documents, whether they are published or not. The documents may come from teaching and research institutions in France or abroad, or from public or private research centers.
L'archive ouverte pluridisciplinaire $\mathbf{H A L}$, est destinée au dépôt et à la diffusion de documents scientifiques de niveau recherche, publiés ou non, émanant des établissements d'enseignement et de recherche français ou étrangers, des laboratoires publics ou privés. 


\title{
The resource curse literature as seen through the appropriability lens: a critical survey
}

\author{
Mehrdad Vahabi (University Paris 13, CPEN)
}

June 2017

\begin{abstract}
There is a vast literature and several surveys on the economic and political resource curse. However, the surveys often fail to capture two points: 1) they disregard the relationship between this recent literature and the staple theory and the staple trap; 2) the appropriability issue has only been treated tangentially and has never been the focus of any survey. The present work fills these gaps. This paper shows that the political resource curse approach initially focused on the appropriability issue through the lens of 'looting' behavior of rebels and distinguished 'lootable' and 'unlootable' goods. However, lootability casts light on mobility of resources or resistance to appropriation rather than state appropriability. Borrowing upon Baldwin's distinction between 'point-source' and 'diffuse' resources, the resource curse literature has recently suggested that state appropriability is related to pointy-resources. The resource curse/blessing assumes that the technical dimension of appropriability and mobility (geographical or purely physical qualities) plays primary role whereas institutional dimensions are either absent or play a secondary role. An alternative approach gives pride of place to the institutional dimension: the same agricultural product such as cereals or coffee can be appropriable or not depending on the institutional structure. Finally, while the literature suffers from a confusion between mobility and appropriability, its relevance in enhancing an appropriative perspective of the state will be underlined.
\end{abstract}

Keywords: Captive and fugitive assets, Lootable goods, Natural resource curse, Pointy versus diffuse resources, Predatory state, Staple theory

JEL classification: $\mathrm{H} 1, \mathrm{H} 4, \mathrm{O} 1, \mathrm{Q} 1$ 


\section{Introduction}

The term natural resource curse was initially coined by economic geographer Richard Auty in 1993. It has been defined as "the perverse effects of a country's natural resource wealth on its economic, social, or political well-being." (Ross 2014, p. 2). But what are 'natural resources'? Different definitions have been offered. In earlier writings (Sachs and Warner 1995; Collier and Hoeffler 1998), they include not only petroleum and other minerals but also agricultural commodities. The latter were excluded in the recent literature since they are produced, not extracted, and hence fail to meet standard definitions of natural resources. Moreover, they are rarely correlated with unfavorable outcomes such as violent conflicts. Presently, natural resources often include petroleum, gemstones, narcotics and other types of minerals. However, certain authors still suggest a broader definition of natural resources to capture non-fuel minerals (Sorens 2011), forest products (Price 2003; Harewell, Farah and Blundell 2011), and commodities more generally (Besley and Persson 2011; Bazzi and Blattman 2014). For Ross (2012), the resource curse is overwhelmingly an oil curse and can be traced back to the early 1980s. Before the eighties, there was not much difference between oil and non-oil states with regard to their tendency towards authoritarian governments or their exposure to civil wars. The curse is particularly relevant to undeveloped and developing countries. Examples abound: Afghanistan (opium, cannabis, and gemstones), Angola (diamond, oil), Colombia (cannabis, gemstones), Democratic Republic of Congo (copper), Iraq (oil), Iran (oil), Kurdistan (oil), Nigeria (oil), Liberia (diamond), Myanmar (opium, gemstones), Sierra Leone (diamonds), and Sudan (oil).

Two different meanings of this curse might be distinguished: 1) the economic resource curse; 2) the political resource curse (for detailed surveys of the literature, see Bulte et al. 2005; Humphreys et al. 2007; Wick and Bulte 2009; Frankel 2010; Van der Ploeg 2011). The former is introduced as "one of the stylized facts of our times" (Wright 2001, p.1) indicating that resource rich countries tend to grow slower than their resource poor counterparts (Auty 1993; Sachs and Warner 1995, 2001). The main economic causes for this type of resource curse that have been identified in the literature are the following: Dutch disease models (Neary et van Wijnbergen 1986; Gelb 1988; Matsuyama 1992; Torvik 2001; Auty 2001a,b; Leite \& Weidmann 2002; Sala-I-Martin \& Subramanian 2003), corruption and rent-seeking models (Acemoglu 1995; Lane and Tornell 1996; Tornell and Lane 1999; Baland \& Francois 2000; Mehlum et al. 2006; Deacon and Rode 2015), and institutional explanations (Atkinson and Hamilton 2003; Auty 2004; Snyder et Bhavnani 2005; Hodler 2006; Boschini et al. 2007; Deacon 2011; Wiens 2014).

The political resource curse initially explored in the pioneering works of Mahdavy (1970), Karl (1997), Collier and Hoeffler (1998), and Ross (1999) has bloomed in the past decade (Morrison 2007; Cuaresma et al. 2011; McGuirk 2013). This strand of works has analyzed the tendency of regimes richly endowed with natural resources to be more authoritarian and more prone to civil wars than those without such resources (Wantchekon 2002; Collier and Bannon 2003; Jensen and Wantchekon 2004; Humphreys 2005; Smith 2007; Goldeberg, Wibbels, and Myukiyehe 2008; Papaioannou and Siourounis 2008; Ross 2009; Aslaksen 2010; Ahmadov 2014). 
Both strands of economic and political resource curse are basically empirical works and employ econometric tests to demonstrate the curse as a stylized fact. Until recently, while most studies report evidence of some type of resource curse, a considerably smaller literature either finds against the hypothesis (Herb 2005), or finds that the effect of natural resources on regime type is conditional on other factors (Dunning 2008). Contrarily to Ross (2001), Haber and Menaldo (2011) and Menaldo (2016) question that had Saudi Arabia not become oil-reliant, it might have developed the same political institutions as Denmark, provided it would have achieved the same per capita income and had fewer Muslims. From an econometric point of view, they argue that it is hard to infer causality when the correlation is produced by a technique that primarily exploits variance between countries. The authors prefer a country-by-country time-series approach and a dynamic panel framework with country fixed effects. Their panel covers 168 countries from 1800 to 2006. Interestingly their results point to a 'resource blessing': "increases in natural resource income are associated with increases in democracy." (Haber and Menaldo 2011, p. 3).

Reviewing his earlier works, Ross (2012, p. xiii) acknowledges that: «To my embarrassment, I found more than a few errors, omissions, and hard-to-defend assumptions. Prompted by some smart skeptics-notably Michael Herb, Stephen Harber, Victor Menaldo, Gavin Wright, Robert Conrad, Michael Alexeev, Erwin Bulte, and Christina Brunnschweiler-I decided to take a fresh look at the data. I discovered some surprises. Things I assumed were true-that petroleum wealth was linked to slow economic growth and weak government institutions-were probably wrong." He concedes that extracting oil does not necessarily lead to abnormally slow economic growth, or does not make governments weaker, more corrupt, or less effective. However, he still underlines the importance of natural (oil) curse since around 1980, and endeavors to explain why some countries have escaped the curse, and how resource curse might be turned into resource blessing in more countries in the future. In his recent survey of the literature, he claims: "Almost all research on the resource curse is based on observational data, which makes it hard to settle these disputes." (Ross 2014, p.2). Similarly, van der Ploeg (2011, p. 366) contends that "empirical evidence suggests that either outcome [curse or blessing] is possible". Thus, the literature now embraces both a pessimist and an optimist viewpoint of natural resources. The conditional impact of natural resources on economic performance is often linked to the quality of institutions. Resource rich countries with bad institutions are often poor and remain poor. But what does determine the quality of institutions? The empirical evidence allegedly lends credence to the assumption that the quality of institutions depends on the appropriability issue.

The political resource curse literature has initially focused on the appropriability issue through the lens of 'looting' behavior of rebels and distinguished 'lootable' and 'unlootable' goods (Le Billon 2001, Ross 2003; Collier and Hoeffler 2004). By 'lootability', it is meant that the natural resource can be easily extracted and transported by individuals or small groups of unskilled workers. Alluvial diamond is a case in point since it has a high value-to-weight ratio, and can be extracted and transported by small groups of unskilled workers. Unlootable resources such as oil, natural gas, and deep-shaft minerals cannot be easily extracted and transported. The importance of resource 'lootability' notwithstanding, it does not embrace state appropriability. In fact, the political resource curse literature began to explore the rebel's behavior and only focused on state behavior since the early 2000s. For example, Auty's 'two-stage process' (2004) is an alternative 
way to look into rebels' behavior by starting to examine the appropriative activity of predatory states as a source of rebellion. Snyder (2006) also underlines the insufficiency of 'lootability' to explain disorder and civil strife, and proposes a political economy of extraction tackling the rulerrebel relationship. In this framework, the main question is to understand who controls the loot. This leads us to state and private appropriability of resources in general and the socio-economic linkages of natural resources with the fiscal revenues. A new distinction between 'point-source' and 'diffuse' resources was suggested to capture the appropriability issue. "The adverse effect of resource dependence on institutional quality and growth is particularly strong for easily appropriable "point-source" resources with concentrated production and revenues and massive rents such as oil, diamonds, minerals, and plantation crops rather than agriculture (rice, wheat, and animals) whose rents are more dispersed throughout the economy, and with easy appropriation of rents through state institutions." (van der Ploeg 2011, p. 384).

Interestingly, this distinction between 'point-source' and 'diffuse' resources has already been made by Baldwin (1956) and other advocates of 'staple theory'. It is surprising that the literature on natural curse has almost completely disregarded 'staple theory' and 'staple trap'. One exception is Auty who acknowledges that his proposal for a 'two-stage process' uses "the staple trap model of resource-driven economic development to explain growth collapses in resource-abundant countries" (Auty 2004, p. 30). In fact, if the major issue is the state appropriability and not lootability, why should natural resource curse or blessing be only studied in the context of today's undeveloped or developing countries in Africa, Latin America and Asia, and exclude the development process of new countries such as Canada, United States, New Zealand, and Australia? Staple theory addressed the same problems as natural resource curse in the case of new settlements among which many are now counted as developed countries. "Nurske included Argentina, Australia, Canada, New Zealand, South Africa, the United States, Uruguay, and possibly southern Brazil as members of this distinctive group." (Schedvin 1990, p. 533). The 'staple theory' was largely a Canadian addition to economic literature. It tried to show how the growth experience of a 'new' country was concretely shaped by the specific primary products (staples) which it successively exported to world markets.

While Mackintosh $(1923,1936)$ provided an optimistic liberal version of steady progress from staple production to a broadly based industrial society, Harold Innis's (1930/1956, 1940/1954) classic studies of the fur trade and the cod fisheries highlighted the problems of external dependence, distortion, and periodic instability that flowed from a reliance on staples. After the Second World War, Staple thesis was generalized and applied to American economic history and other countries by North (1955, 1956, 1958, 1959), Baldwin (1956), Watkins (1963), Hirschman (1977), and Caves $(1963,1971)^{1}$. Similar to the resource curse/blessing literature, two opposite optimist and pessimist versions of staple thesis were advocated. While "there was a pronounced

\footnotetext{
${ }^{1}$ Although the theory is originally Canadian, some authors have formulated it independently in other contexts. For example, Shafer (1994) develops a sectoral analysis of the developmental prospects of states according to which a state's capacity to enhance economic development depends on the "attributes of the leading sector through which it is tied to the international economy: light manufacturing, mineral extraction, peasant cash crop production, or industrial planation crop production." (Ibid, p. 2, emphasis added). While he never explicitly quotes the staple theory, he rediscovers it through his comparative political economy.
} 
shift towards acceptance of the pasteurized Mackintosh version, Baldwin used the model to explain how the Old South was caught in a "staple trap"' (Schedvin 1990, p. 534).

For many authors, 'staple trap' implies a distinction between a 'bad' (point-source) and a 'good' (diffuse resource) staple according to their appropriability. A 'bad' staple is the equivalent of 'resource curse' and a 'good' staple is a 'resource blessing'. The resource curse/blessing literature mainly consists of empirical econometric tests but the early formulation of staple theory is theoretical though unsupported by econometric tests. The recent generation of staple theory models are backed by econometric tests (Engerman and Sokoloff 1997; Sokoloff and Engerman 2000; Nugent and Robinson 2010) and are often amalgamated with the resource curse literature.

The purpose of this paper is to critically review the resource curse literature through the appropriability lens. However, since the underpinning tenets of the resource curse literature on appropriation are directly borrowed from staple theory, I will systematically highlight the contributions of this theory that are often unfortunately unnoticed in most empirical econometric studies. The paper is organized as follows. The second section reviews the staple trap and highlights its commonalities as well as divergences with the resource curse. The third section explores lootability and shows why this concept is germane to understand the mobility (or immobility) of resources. The fourth section studies the appropriability issue both in the resource curse literature and the staple theory. The fifth section examines the technical and institutional dimensions of appropriability issue. The sixth section identifies various determinants of mobility and appropriability and argues the relevance of the resource curse literature as well as staple theory in enhancing an appropriative perspective of the predatory state. A short conclusion will follow.

\section{Staple trap and resource curse}

The term "staple" refers to the chief commodity produced by a region. It is customarily regarded as describing plantation and non-plantation products, fishing and products of extractive industry. Certain authors employ the term as synonymous of 'exportable commodities and services' (North 1955, pp. 247-8). According to Watkins (1963, p. 144), the central concept of a staple theory is "the spread effects of the export sector, that is, the impact of export activity on domestic economy and society." To construct a staple theory, it is then necessary to follow Leontief-type input-output relationships, and classify these spread effects and indicate their determinants. In Hirschman's terms (1958, chap. 6), the inducement to domestic investment resulting from the increased activity of the export sector can be broken down into three linkage effects: backward, forward, and final demand linkages. The staple theory can then be formulated as a theory of capital formation.

Backward linkages lead to new investments in input-supplying facilities and influence the pattern of investment activity, notably transport for collection of the staple. Forward linkages are a measure of the inducement to invest in industries using the output of the export industry as an input; they often stimulate processing and service industries. Together with the final demand linkage, which measures the derived demand for consumer goods from staple production, these relationships determine the strength of the spread effects from the staple to the economy as a 
whole ${ }^{2}$. In addition to these three forms of direct physical (or production) linkages, there is a fiscal linkage of the staple that measures the ability of the state to tap the income stream accruing from the staple to various parties. The spread effects or linkages between the staple and the domestic economy may lead to economic diversification. This is an optimistic version of the staple theory advocated by Mackintosh (1923, 1936). During the 1950s and 1960s, most authors shared this version and believed in the potent force of staple production for long term economic development thanks to linkage effects. Considering the Canadian experience, Watkins (1963) supported that the spread effects were mainly one of diversification around an export base. The idea that a staple might lack necessary linkages to other parts of domestic economy and fail in generating diversification was suggested by some economists but was not considered as a likely outcome except in the special case of a slave-based economy. This possibility was dubbed a 'staple trap'.

Baldwin (1956) intimated the idea of a possible 'staple trap' by introducing a bipolar economy comprising of plantation-type economies (like cotton or sugar) based on slave or cheap labor and non-plantation type commodities such as wheat. "At one end stand the plantations employing large quantities of low wage labor. The other end of the scale is composed of many small, family cultivators who operate under a tenure system or perhaps own their land." (Baldwin 1956, p. 171). He argued that the plantation economies had no positive linkage with education and transport sectors. The large, low income labor supply in plantation possessed such a low level of education and skill that its costs of training represented a large, initial outlay; and they were so impoverished that the provision of transportation facilities (other than the minimum necessary for the export crop) proceeded very slowly (Baldwin 1956, pp. 172-73). By contrast, non-plantation economies such as wheat were prone to education and transportation. "[T]he region with more equitable income distribution will be well aware of the stake in improving its comparative position through education and research and will accordingly be willing to devote public expenditures in these directions." (North 1959, p. 946). North also underlined the backward linkages of wheat to transport notably the railroad. "The expanded foreign demand for wheat in 1846-47 led to a revival in westward expansion and stimulus to extension of railroads." (North 1958, p. 70).

Inspired by Baldwin's bipolar economy, Perloff and Lowdon (1961) suggested a distinction between 'good' and 'bad' resource exports in the American regional growth. While the economy may get caught in a 'staple trap' due to its reliance on a 'bad' staple, it can enjoy sustainable growth because of diversification induced by a 'good' staple. Staple trap is the equivalent of resource curse since it blocks the diversification process. Hirschman (1977, p. 95) strongly disagreed with this dichotomous vision of staples: "in almost all of these pairwise comparisons one staple is assigned the role of all-around villain, while the other is the all-around hero... In Cuba sugarcane is the villain and tobacco the hero, in Colombia tobacco is the bad guy while coffee is the good guy, and in Brazil sugarcane is once again the villain while coffee is the good guy (note that as a result of these three pairwise comparisons, the ordering of the three staples is actually transitive!)."

\footnotetext{
${ }^{2}$ Several formalized versions of the staple theory have been formulated. Caves (1963) offers an elegant model of 'vent for surplus' and suggests a connection with neoclassical growth theory.
} 
While Hirschman disagreed with the distinction between 'good' and 'bad' staples, he furnished some evidence for a staple trap in the case of oil industry and 'enclave' economies in general. By 'enclave', Hirschman (1977) meant a staple like oil and other similar mining activities that do not involve the rest of the economy, and do not have any productive backward, forward, or final demand linkages. In an enclave economy, fiscal linkages become particularly determinant. It is precisely because of this absence of connections that the enclave becomes an obvious and comparatively easy target of fiscal authorities. "Being a foreign body, often owned by foreigners to boot, the enclave has few defenders of its interests once the state acquires the will and authority to divert toward its own ends a portion of the income stream originating therein." (Hirschman 1977, p. 74). In this sense, strong fiscal linkage in an enclave economy is contradictory with other forms of linkages. In fact, if there was a productive activity with many direct links to the rest of economy, either because of strong backward and forward linkages or, more simply, because it is carried on in the central region of a country by producers with intimate ties to a dense network of traders and townspeople, then fiscal linkage would be difficult. "Clearly, with so many friends in court this activity is not likely to be subjected to significant special taxation. The situation that is brought to mind here is that of coffee-growing countries such as Brazil and Colombia" (Hirschman, Ibid, p. 75).

Interestingly, similar to Hirschman the recent contribution of Mitchell (2011) opposes coal to oil's supposedly curse-like properties from the viewpoint of production process. He gives pride of place to the power of coal miners to strike as the basis for gaining the rights to vote, to organize, and to create political parties and to democratize European countries in the late nineteenth and early twentieth centuries. The linkage effect in the coal industry is explored through the strike movement that spread to other interconnected industries of coal mining, railways, docking and shipping sectors. In the same vein, Mitchell notes that the oil mines had similar effects in the early twentieth century. For example, the oil industry in Baku (in modern-day Azerbaijan) launched protests that would eventually result in the 1905 Russian revolution. The ripple effect in oil industry in Baku was due to the fact that "The proximity of wells, workshops, pumps, power supplies and refineries created a concentrated labor force with the ability to disrupt supplies of energy across a broad region." (Mitchell 2011, p. 34).

According to Mitchell, international oil companies and governments learnt from these early movements. They restructured the management of oil extraction to eschew worker pressures. For example, given the distance between oil mines and industrial centers, they exploited ethnic divisions or emigrant workers to insulate the oil industry in many countries. Moreover, various types of transport (maritime, pipeline, etc.) were developed to protect the delivery of oil in case of workers strikes. Although social historians do not always agree with Mitchell's diagnostic of the workers' movement in oil industry (see for example Atabaki, forthcoming), his contribution is an addition to staple theory by identifying a new linkage effect, namely industrial conflict. 
Despite the original optimist orientation of staple theory, the later version of this theory was more pessimist since diversification never happened in Argentina, Brazil, South Africa, and Uruguay ${ }^{3}$. According to Schedvin (1990, p. 535): "From a late twentieth-century viewpoint, the task of successful diversification from an original export base seems to have encountered more obstacles than the postwar growth optimists expected... It appears that Canadian experience is the exception rather than the rule." Staple trap is the precursor of resource curse. However, the former is clearly established on linkage effects whereas the latter is primarily an empirically based relationship supported by a battery of econometric tests. Furthermore, while the former describes the development issue in 'new' countries, the latter is limited to undeveloped and developing countries. Finally, compared to resource curse, staple theory covers a broader group of commodities including agricultural products such as wheat, tobacco, coffee, sugar as well as fishing and extractive industries. Contrarily to staple theory, the narrower definition of resources precluding agricultural products is particularly stressed in political resource curse literature: "It is more accurately a mineral curse, since these maladies are not caused by other kinds of natural resources, like forests, fresh water, or fertile cropland." (Ross 2012, p. 1, the emphasis is added). Politically speaking, the curse is related to unfavorable outcomes such as intra and inter-states warfare.

\section{Lootability and Mobility}

Hirschman's theory of 'staple trap' is related to a contradictory relationship between fiscal linkage and other types of production linkages. State appropriability is central in this framework. Contrarily to this approach, the issue of appropriability has been initially taken on board in the resource curse literature with regard to lootability of resources by rebels. The term 'lootable goods' was coined by Le Billon (2001, p. 569) to describe primary commodities that "are often highly amenable to taxing and looting. This lootability arises in part from the fact that resources, and in particular extracted ones, are often easily accessible to governments and rebels alike with minimal bureaucratic infrastructure. Furthermore, resource extraction activities are, to a greater degree than other economic activities, spatially fixed." Based on empirical observations, Ross (2003) argues that among all principal types of natural resources, gemstones (diamonds) and narcotics (opium, cannabis, and coca) have been strongly related with the civil wars during 1990 and 2000. These goods are distinguished from oil, natural gas, and deep-shaft minerals as "unlootable goods". Although lootable goods are spatially fixed, they are "lucrative and easy-to-transport resources" (Snyder 2006, pp. 943-944).

Following Le Billon (2001), Ross (2003) underlines the significance of "lootable goods" in civil wars and identifies three major characteristics for such goods: 1) lootability; 2) obstructibility, and 3) legality. "A resource's lootability is the ease with which it can be extracted and transported by individuals or small teams of unskilled workers...A resource is obstructable if its transportation can be easily blocked by a small number of individuals with few weapons...Finally, most resources

${ }^{3}$ It seems that Kindleberger (1958, p. 14) was quite right in modelling three scenarios with regard to the impact of foreign trade on economic development, namely leading, lagging, and balancing effect. 
can be legally traded on international markets: drugs-coca, opium, cannabis, and their derivativesare the main types of illegal natural resources." (Ross 2003, p. 54). Among these three characteristics, lootability is regarded as the most important one and the two others as secondary.

There is a major difference between Le Billon's definition of 'lootable' goods on the one hand, and that of Ross (2003) and Collier and Hoeffler (2004), on the other hand. The former defines 'lootable' goods with regard to taxing (government) and looting (rebels) whereas the latter associates 'lootable' uniquely with the rebel. Lootable as 'stealable' is also noted by Leeson (2007 p. 313) who cites ivory, rubber and wax as "thievable" goods. They are resources that have a high value-to-weight ratio, such as gemstones, coca, and opium. The greater this ratio, the greater the distance over which an asset might be traded. The reason is that a higher ratio means a greater amount of traded value covering the costs of transportation incurred in longer distances. Precious commodities such as silk, gold, gemstones, aromatic woods, pepper, rare medicines, and tea were non-bulky goods that were worth transporting on long distances. They connected centers to peripheries on the basis of exchange rather than political domination. Historically, distant trade was generated on the basis of this type of products. But 'lootability' in this sense is not synonymous with state 'appropriability'. In fact, unlootable goods are associated with state appropriability, since they include immobile assets such as oil, natural gas, and deep-shaft minerals ${ }^{4}$. Such goods are prone to state appropriability but are regarded as unlootable goods. "The more lootable a resource is, the more likely it is to benefit a rebel group; the more unlootable it is, the more likely it is to benefit the government." (Ross, 2003, p. 56). Hence what Ross calls lootable goods are goods that can escape from the state space and be appropriated by rebels. Lootability refers to the capability of escaping or mobility that should not be conflated with state appropriability.

Vahabi (2016a, chapter 6; 2016b, pp. 157-160) has distinguished 'mobility' from 'confiscability' (coercive appropriation) by the state. In a prey-predator relationship, appropriability depends on the ability of the predator to capture and appropriate the prey, whereas mobility refers to the ability of the prey to escape. The non-market exit option of an asset hinges upon two distinct criteria: 1) mobility, 2) inappropriability (non-confiscable). Appropriability determines the benefits of predation and mobility decides the costs of predation.

"1. Mobility: capable of escaping from a given state space, because they can be easily hidden or displaced geographically; this also refers to the possibility of altering political allegiance without any geographical displacement.

2. Non-confiscable: hardly subject to confiscation because (1) any attempt to transfer property rights through coercion destroys the asset or reduces its value to almost nil, and (2) the costs of confiscation are greater than the benefits of confiscation." (Vahabi 2016b, p. 158).

Asset mobility is firstly defined by the easiness of geographical displacement, or the high ratio of value to weight and volume, such as alluvial diamonds. Physical or geographical change in

\footnotetext{
${ }^{4}$ Collier and Hoeffler $(1998,2004)$ claim that primary commodity exports tend to augment the probability of civil war. Some other econometric tests about the relationship between civil war and natural resource do not confirm this result (Fearon and Laitin 2003, p. 87; Elbadawi and Sambanis 2002, pp. 324-325; Hegre 2002). However, empirical tests often support that lootable commodities like gemstones and drugs are correlated with non-separatist civil wars, whereas oil as an unlootable good is linked to the onset of separatist civil war (for a general survey, see Ross 2004).
} 
location is determinant in this respect. Since the state has a power gradient depending on the remoteness from the state center (Boulding 1960), there are geographical zones over which the state exercises less influence. These areas are inaccessible or hardly accessible for the state. Steep hills, marshes, tropical forests and deserts have always been natural refuge zones for escapees throughout history. People living on the borderlines of two or several states also detain an advantageous position in terms of mobility by crossing the frontiers (e.g., Kurds and Baluchis). They may profit from their exit power to reduce the amount of taxes. A salient illustration is discussed by Douglass North (1981) regarding lower taxes imposed upon border areas in medieval Burgundy due to competition between feudal lords.

Similarly, Le Billon (2001) drawing on Auty (2001a) makes a distinction between resources that are proximate to a national capital (and hence easier for governments to capture) and those that are distant (and hence easier for rebels to hold). Auty (2004) largely concurs with Le Billon, and introduces the concept of 'dangerousness of a resource' which is correlated with two factors: 1) its value-to-weight ratio; 2) porous national borders. Resources with higher ratios, like diamonds and drugs, are likely to pose greater hazards than those with low ratios, like agricultural commodities. But resources with lower ratios might also be dangerous in the presence of remote frontiers. "Porous national borders that are remote can permit even low value/weight products like timber to generate mobile rents. Significantly, alluvial gems and drugs create point linkages and have a high value to weight that renders most national borders porous. Ross confirms that these commodities exhibit the highest incidence of conflict." (Auty 2004, p. 46)

Mobility in a broader sense includes the invisibility property of assets. Although mobility and invisibility are two different properties, they share a common quality in the context of predation: inaccessibility to be tracked down. Agricultural crops having the hidden ability like roots and tubers (manioc, cassava, potatoes, taro, yams, yucca, etc.) are salient illustrations of 'escape crops'. Scott (2009, Chapter 6, pp. 178-219) has extensively studied several characteristics of this type of crops that facilitate evasion of taxing or confiscation by states. In many cases, they simply qualify by being well adapted to ecological niches that are difficult to map and control: high, rugged mountains, swamps, deltas, mangrove coasts, etc. "Cultivars that require little attention and/or that mature quickly are also state repelling inasmuch as they afford more mobility than labor-intensive, long maturation crops. Unobtrusive crops of low stature that mimic much of the natural vegetation around them thwart appropriation by being easy to overlook. The greater the dispersal of the crops, the more difficult they are to collect, in the same way that a dispersed population is more difficult to grab." (Scott 2009, p. 196). Potato is another example of root crops that can insulate states as well as stateless peoples against the predations of war and appropriation. McNeil (2007) attributes the early eighteenth century rise of Prussia to the potato, while Nunn and Qian (2011) show the potato's contribution to population and urbanization in Old World between 1700 and 1900 . Following the terminology of resource curse literature, why cannot 'escape crops' be classified as both 'lootable' and 'dangerous'?

If 'lootability' refers to the capability to escape from state space, then contrarily to what is often claimed in the resource curse literature, some agricultural products, namely 'escape crops' should also be regarded as 'lootable' and 'dangerous', since they support rebels and escapees and are 
prone to thwart state appropriability. In this sense, lootable goods embrace not only 'expensive' gemstones and narcotics but also some 'poor' ordinary escape crops. As underlined above, lootability addresses mobility and not state appropriability. To understand this latter issue, the focus should be shifted from rebels to rulers and states. A major controversial issue on the motivations of rebels ('greed versus grievance') was perhaps one of the elements that delayed this shift for some time.

Advocates of 'greed' assumption were often focused on rebels' motivation rather than predatory states, since: "Only a small minority of any society are psychopathic, but these people are likely to be in the front of the queue for rebellion." (Collier 2009, p. 135). In dire contrast, proponents of 'grievance' assumption, sought the roots of civil war in the state's unjust behavior. Collier and Hoeffler (1999) and Collier (2000, 2007, 2009) aver that greed variables predict civil war better than grievance factors do. Injustice might exist but it does not necessarily provoke resistance. Moreover, rational insurgents are assumed not to follow their leaders' slogans about social justice since there is a problem of time-inconsistency, i.e. no credible commitment by leaders. They may defect and renege on their mobilizing pledges. Instead, appealing to people's motivation for immediate satisfaction through looting may solve the collective action dilemma. To test their hypotheses, the authors constructed proxies for greed and grievance.

The share of primary commodities in total exports, the ratio of young males in the total population, and the number of years devoted to schooling among young males are supposed to be the elements of a composite indicator that measures greed or loot-seeking. The rationale for this proxy is that it tallies the ease of immediate taxation by looting. The average years of schooling pertains to other economic occupations accessible to young males relative to the use of violence or looting. Grievance or justice-seeking is represented by another composite indicator including ordinary economic indicators for growth in the five years prior to the outburst of conflict, scores of repression and restricted political rights, inequality and ethno-linguistic fragmentation. In Collier (2000), socio-economic grievance is measured in terms of 'vertical' inequalities i.e. income or land ownership inequalities among individuals or households rather than social groups. According to the data, vertical inequality has no effect on the risk of conflict. But what about 'horizontal' inequalities?

Based on an extensive study of violence in multiethnic societies, Stewart and her associates (2008) argue that empirical evidence lends credence to the assumption that grievance in terms of horizontal inequalities, namely "inequalities in economic, social or political dimensions or cultural status between culturally defined groups" (Stewart 2008, p. 3, emphasis is added) are major sources of civil wars. Horizontal socio-economic inequalities have not always led to civil wars. Bolivia, Ecuador, and Ghana are a few cases that have been explored by the contributors to Stewart (2008). The authors suggest that in those cases, the leadership of disadvantaged minorities has been politically coopted by the dominant group. To put it differently, the pursuit of a politically and economically inclusive strategy by the ruling group tends to ameliorate social conflicts.

Moreover, the proponents of the 'grievance' assumption have critically assessed the proxies of Collier and Hoeffler. For example, Cramer (2002, pp. 1851-1854) discusses several shortcomings of these proxies and considers them as a "patchwork". Keen (2012, pp. 761-62) questions Collier and his associates' proxies for greed and grievance. For instance, lack of access to education is 
taken as a proxy for greed. However, Keen (2005) persuasively argues that lack of access to education might justifiably be coded as a proxy for grievance in cases like Sierra Leone. Similarly, Collier, Hoeffler and Söderbom (2006) consider low per capita income and low slow growth as proxies for the feasibility of rebellion, since they reduce the recruitment cost of rebel army. But they might be better as proxies for grievance. The problem is that by changing the meaning of proxies, one can arrive to diametrically opposite results.

The advocates of the grievance approach do not deny the role of greed or economic motivation in fueling violence. In fact, they were among the pioneers of studies about war yielding benefits and economic beneficiaries of conflict (Keen 1994, 1998; Reno 1997; Stewart and Fitzgerald 2001; Duffield 2001). However, these authors insist on a dynamic and complex interaction between greed and grievance (Keen 1994; Ballentine and Sherman 2003). They claim that even in situations where greed furnishes a strong driving force for violence, a variety of grievances underpin greed. For example, the link between natural resources and conflict is well established. But while proponents of the greed perspective often interpret this link as 'rebel greed', Stewart, Brown and Langer (2008, p. 294) note that "the conflict-inducing potential of natural resources is often mediated through their impact on HI [horizontal inequalities], and that this can translate both separatist struggles and local-level conflict." Grievance breeds greed and vice versa. Grievance may cause war, but war and predation generate, in their turn, inequalities, lack of trust, severe shortages and greed in having access to desired scarce foods, energy or other resources. Similar to proponents of 'grievance' thesis, Mann (2005, p. 516) criticizes Collier and Hoeffler with regard to the recent African insurgent movements: "Most African insurgent movements begin with genuine organic nationalist ideologies; only later do they degenerate under conditions of civil war stalemate into criminality."

Auty (2004) and Snyder and Bhavnani (2005) suggested a "two-level analysis" that starts with the state's behavior to capture the rebel's behavior. "Collier and Hoeffler (2004), and Fearon and Laitin (1999)...do not address the crucial prior question of how governments get (or fail to get) the revenue to pay for military expenditures in the first place. Our integrated focus on government revenue and spending gets beyond this limitation." (Snyder and Bhavnani 2005, p. 567). Accordingly, the authors propose an alternative framework: "Our framework departs from previous research on resources and civil war by shifting the focus from rebels to rulers and states, analyzing the institutional and economic constraints that determine the ability of rulers to get the income with which to govern, and combining this focus on revenue with a focus on spending." (Ibid., pp. 565-566). Instead of 'lootability' or mobility, they suggest to first study state appropriability or 'unlootable' goods. This leads to a revenue-centered theoretical framework that shifts the focus from rebels to rulers and states, and situates rulers in the context of the institutional and economic constraints on their ability to earn revenue, and combines this focus on revenue with a focus on state spending.

This is exactly the same line of research that Auty (2004) had suggested in his "two-level analysis". But starting with state appropriability instead of lootability brings the resource curse literature closer with the staple theory. Interestingly, Auty is one of the rarest authors who explicitly refers to the staple trap: "This article...uses the staple trap model of resource-driven economic development to explain growth collapses in resource-abundant countries, which appear to be a necessary pre-condition for civil strife, but not a sufficient condition. The study therefore goes on 
to identify two basic properties of natural resources related to civil strife, namely the pattern of socio-economic linkages produced by the commodity and the mobility ('lootability' in the terminology of Ross) of the resource rent. The socio-economic linkages may be either 'point source', which means they are concentrated on a handful of economic agents, like large-scale mining, or they may be diffused among many agents, like peasant crops. The former are more likely to engender conflict." (Auty 2004, p. 30). This passage is very important since it clearly acknowledges that lootability only captures mobility and not state appropriability. Moreover, Auty concedes that the staple trap may provide a theoretical explanation for political resource curse. Finally, he clearly builds his model on Baldwin's bipolar economy: a pointed-resource (mining) and a diffused one (peasant crops like wheat). The former plays the role of the bad guy and is assumed to be the source of civil strife, while the latter is the good guy. Interestingly, the distinction does not preclude ordinary agricultural products.

\section{Pointy versus diffuse resources and appropriability}

The distinction between pointy versus diffuse resources on which Auty (2004) built his staple trap model could be traced back to Auty (2001a, b). Analyzing transition economies, Auty (2001a, b) pointed out that resource-rich countries with pointed-resources like oil fields are conducive to predatory oligarchic governments, fractional polities promoting narrow sectional interests. These countries drift toward bad policies and suffer from rentier effects and are often hindered from diversification and competitive industrialization. To put it differently, pointy or concentrated resources lack socio-economic linkages to enhance economic growth but are prone to appropriative activity. By contrast, diffuse resources involve socio-economic linkages and promote productive activity leading to capital accumulation. Baldwin's division of resources into pointy and diffuse strongly influenced Auty's work in understanding the appropriability issue.

Baldwin's bipolar economy has been adopted by other versions of staple theory in which pure geographical factors play a deterministic role. While Baldwin and Hirschman's view advocates socio-economic linkages, a recent version of staple theory adopts a purely geographical distinction of resources. In Baldwin (1956), pointy resources are distinguished from diffuse resources with respect to the presence or absence of socio-economic linkages rather than geographical dimension. While diffuse resources induce socio-economic linkages such as transport and education, pointy ones do not generate them. According to Watkins (1963, p. 147): "In the plantation case, the dominant group with its rentier mentality on the one hand, and the mass of slaves who are prevented from bettering themselves on the other, can produce a set of institutions as inimical to entrepreneurial activity as is to be found in any tradition-ridden society. Business pursuits may be castigated as "money grubbing"; education-which, as North has emphasized, is very important-is likely to be confined to the elite and to slight the development of technical and business skills; political activity tends to be devoted to the defense of the status quo. On the other hand, in the family-farm case, as in wheat areas, the more equal distribution of income can result in attitudes towards social mobility, business activities, education, and the role of government which are more favorable to diversified domestic growth." Hirschman (1977) prolonged Baldwin's and Watkins' versions of staple theory in which a staple's impact on the whole economy through various forms of linkages becomes a theory of capital formation. He also added fiscal linkage to other forms of linkages to capture the role of state in the economy. 
By contrast, a recent version of staple theory modelized by Engerman and Sokoloff (1997), Sokoloff and Engerman (2000) does not follow Baldwin's bipolar economy and suggests a tripartite classification of New World colonies on the basis of purely geographical distinctions. This version is supported by econometric tests and conflated with resource curse literature. The tripartite classification is as follows.

1) Staple crops like sugar and other highly valued crops associated with large slave plantations in the West Indies, Barbados, Cuba, and Jamaica, as well as in South America (mainly Brazil). In this category, the overwhelming fraction of the populations was black of African descent. The distributions of wealth and human capital were extremely unequal among free and slave populations. 2) Rich mineral resources combined with substantial numbers of natives surviving contact with the European colonizers in Spanish America, some islands in the Caribbean, and colonies such as Mexico and Peru. "Building on preconquest social organizations, whereby Indian elites extracted tribute from the general population, the Spanish authorities adopted the approach of distributing enormous grants of land, often including claims to a stream of income from the native labor residing in the vicinity, and of mineral resources among a privileged few" (Sokoloff and Engerman 2000, p. 221). 3) European descent small-owners producing grain in the northern part of the North American mainland-chiefly those that became the United States, but including Canada as well. "Compared to either of the other two categories of New World colonies, this class had rather homogenous populations... With abundant land and low capital requirements, the great majority of adult men were able to operate as independent proprietors" (Ibid, p. 223).

This tripartite division of 'new' economies is based on factor endowments, and the relative relationship of free/unfree labor to abundant/scarce land. The origins of appropriative regimes in the first two types of economies versus productive regimes in the third one are sought in initial factor endowments. Accordingly, the institutional differences are explained by purely geographical distinctions: "In this chapter, we explore the possibility that the role of factor endowments has been underestimated and the independence of institutional development from the factor endowments exaggerated." (Engerman and Sokoloff 1997, p. 261). This version of staple theory has found an important echo in the resource curse literature.

Auty's distinction between diffuse versus pointy resources has been a source of inspiration for many other authors in the resource curse literature like Le Billon (2001, p. 570), Ross (2003, p. 53); Isham et al. (2005, pp. 141, 143, 150-152); Bulte et al. (2005, pp. 1031-32), Wick and Bulte (2006, pp. 457, 461-462), Boschini et al. (2007, p. 597); Busse and Gröning (2013, p. 3), as well as Wiens (2014, p. 218). While Auty's distinction between pointy versus diffuse resources is based on Baldwin's version of staple theory, his followers in the resource curse tradition have often advocated a purely geographical distinction. For example, Isham et al. (2005, pp. 148-149) explicitly refer to Engerman and Sokoloff (1997) and Sokoloff and Engerman (2000) in defining diffuse versus pointy resources as 'factor endowments' and Bulte et al. (2005, pp.1031-32) contend that point resources are extracted from a narrow geographic or economic base and include oil, minerals, and plantations. Since these resources are spatially concentrated, they can be protected and controlled at a relatively modest cost. The implication is that countries with abundant point resources end up with worse institutions, and their governments perform poorly along several 
dimensions. Conversely, countries with abundant diffuse resources show no tendency to pursue this pattern. Similarly Wick and Bulte (2006, p. 457) state that "economies that are abundantly endowed with diffuse resources (resources spread thinly across space), typically grow faster than countries with resources that are geographically clustered (or "pointy"). Similarly, Ross (2004) shows that pointy resources trigger and prolong conflicts whereas diffuse resources do not."

The problem with both geographical and economic-linkage description of resources is that they both disregard the specific institutions in which any natural resource might be used by economic agents. For example, the production of wheat or cereals may be diffused or concentrated depending on the institutional structure (particularly property rights) in which they are produced.

Certain leading theorists of the staple theory are cognizant of the relevance of institutions in defining diffuse staples. Borrowing Baldwin's bipolar economy to explain the American economic growth, North $(1955,1956,1959)$ underlines in the first place the difference between the American market-oriented agriculture with the European subsistence economy. "From the early joint-stock companies on through the whole westward expansion, a basic objective was to exploit the land and its resources in order to produce goods that could be marketed "abroad" and would bring in a money income. This is in marked contrast to the experience of Europe (which appears to be the model for the early stages of the theory of regional economic growth), where a market-oriented economy emerged only gradually from the predominantly local economies of manorial system. If a subsistence economy existed in a new region in America, it was solely because of a lack of means of transport, a condition that was swiftly remedied by the concerted efforts of the settlers." (North 1955, pp. 245-246, emphases are added). The wheat exploitation in the U.S. in the nineteenth century was diffused since it was based on small-private market-oriented production. The diffusion in wheat production was neither geographical nor economic. Geographically speaking, cereals should be considered as a pointy resource, since they were grown on densely concentrated alluvial or loess soils. From an economic linkage point of view, cereals have always been the nervous system of most economies and can be described as diffuse if this quality is attached to crops conducive to large socio-economic networks. But if diffuse implies hardly appropriable, then cereals are not qualified to be diffuse. In this latter sense, they are rather pointy, since historically speaking, cereals have always been one of the most appropriable crops.

Indeed, as Scott (2009, Chapter 3, pp. 64-97) has already shown, all the pristine agrarian states in Mesopotamia, Egypt, Indus Valley, and Yellow rivers, were grain states: wheat, barley, and millet (in the case of Yellow River). If state is understood as an institution of coerced appropriation of labor and resources or tax-collection by a specialized hierarchical bureaucracy of officials, then all the archaic states were based on concentrated manpower, grain slavery and irrigated rice. "Conditions in a flourishing wet-rice heartland, then, were favorable to the development of what might be called the premodern state's ideal subjects. That ideal is represented by density packed cultivators of permanent grain fields who produce a considerable annual surplus. Having put considerable labor into their padi fields, over generations, perhaps, they are all reluctant to pack up and leave. They and their rice fields are, above all, fixed in space, legible, taxable, conscriptable, and close at hand." (Scott, Ibid, p. 65). There is an intimate relationship between cereals and state formation, since only this crop could serve as the foundation of taxation. Contrarily to 'escape 
crops' discussed in the preceding section, cereal grains are visible, legible, storable, and divisible. "A premodern ruler in mainland Southeast Asia would have been less interested in what today would be called the gross domestic product (GDP) of his kingdom than what we might call its "state-accessible product" (SAP!)...The state-accessible product had to be easy to identify, monitor, and enumerate (in short, assessable), as well as being close enough geographically." (Scott, Ibid., p. 73). In short, Scott distinguishes two types of cultivars with regard to stateappropriability. Cereals are state-appropriable whereas tubers and roots are escape-crops in noncapitalist, non-market economies based on forced labor. The former is the basis of state space, the latter is state-repelling.

Scott's idea has been recently modelized by Mayshar et al. (2015) ${ }^{5}$. The authors propose that the emergence of social hierarchy in the aftermath of the Neolithic Revolution was because of the elite's capability to appropriate cereal crops from cultivators and not a result of land productivity as claimed in conventional theory. "Thus, regional differences in the suitability of land for roots and tubers, which are less appropriable, or cereals, which are more appropriable, can lead to differences in the formation of hierarchy and state institutions, and thereby explain persistent differences in economic development." (Ibid, p. 1).

The appropriability of cereals has several implications: 1) ordinary agricultural products should not be excluded in discussing the appropriability issue. Historically, cereals were at least as (if not more) important as oil and minerals in state-building. Similarly, escape-crops were at least as (if not more) important as diamonds and narcotics in helping rebels and escapees to resist the rulers. 2) The distinction between pointy and diffuse is not purely geographical or economic but also institutional. Geographically concentrated grain on alluvial soil might be treated as institutionally diffuse or pointy depending on the property rights. For example, in the absence of world market, the grain produced in a subsistence economy under a communal or slavery system might be treated as a pointy resource whereas the same agricultural product produced for world market economy under small private ownership of land is a diffuse resource. Cereals in their 'natural state' provide only the object of appropriation but their appropriability is conditioned by enforced institutional rules. Hence, the appropriability issue entails both technical (physical qualities including geographical location) and institutional dimensions.

\section{Technical and institutional appropriability}

A natural resource is an economic asset when it becomes appropriable. According to the property rights school, an asset is valuable not only because of its physical properties, but rather by the allowed rights of action over the asset. "(T)he value of what is being traded depends upon the allowed rights of action over the physical good and upon the degree to which these rights are enforced" (Demsetz 1964, p. 18). There are two important concepts in Demsetz's definition of economic value, namely 'right' and 'enforcement'. This brings us to delineation and enforcement of property rights. Both of them are costly and it would be necessary to balance the benefit from

\footnotetext{
${ }^{5}$ Unfortunately, the authors do not acknowledge Scott's pioneering work in this respect. While their model captures Scott's distinction between these two types of cultivar in archaic agricultural economies, their approach to the state as provider of public goods (Mayshar et al., Ibid, pp. 4,6) is diametrically opposite to Scott's viewpoint of the state as a predatory institution.
} 
delineating property rights against the costs (Cooter and Ulen 2012). Purely physical characteristics of natural resources cannot be the source of any 'curse' unless these resources have been transformed into assets. In fact, when Humphreys et al. (2007), Ramsay (2011), Beck (2011) and Ross (2012) consider the 'volatility of oil revenues' as a major source of oil curse ${ }^{6}$ and as a "collateral", they assume that what is decisive is that oil is no more a pure natural resource but an economic asset. In this sense, 'appropriability' necessarily entails two dimensions: technical and institutional.

According to Boschini et al. (2007, p. 594), the effect of resources is not determined by resource endowments alone, "but rather by the interaction between the type of resources that a country possesses, and the quality of its institutions. This combination of factors determines what we call the appropriability of a resource." Two major issues are raised in this passage: 1) the type of resources rather than the 'abundance' of resource endowments in general is important in understanding the effect of resources on the appropriability; 2) the incidence of specific type of resources on the appropriability is conditional on the institutional quality.

The first issue is ignored in a strand of work concerning the impact of natural resources on appropriability. For example, the "voracity effect" (Lane and Tornell 1996, 1999) measures the extent of rent-seeking or appropriative activity of organized powerful groups following an increase in the rate of return of common resources such as oil. Put differently, any increase in the oil revenue in Venezuela, Nigeria, or for Trinidad and Tobago where such powerful groups are dominant, provoke a voracity effect: the private consumption of these groups surpasses the amount of increase. The appropriative activity of powerful groups reduces growth rate due to the voracity effect. The model ignores the specific institutional matrix of society. In the same vein, Torvik (2002) has developed a theoretical model of rent-seeking where resource abundance increases the incentives to invest in 'grabbing' activities to capture the rents from the resources. These papers predict a monotone-adverse effect of natural resources on economic growth and they do not differentiate between the effects of different types of resources.

By contrast, Auty (1997), Woolcook et al. (2001) and Isham et al. (2005) have emphasized the importance of different types of resources. While Boschini et al. (2007) follow this line of research, they underline that the relationship between natural resources and growth is non-monotonic in institutional quality and differently so depending on the type of resources (Boschini et al., Ibid, p. 597). Their result is in tune with Mehlum et al. (2006) predicting that resources have a nonmonotonic effect on growth depending on the quality of institutions. Mehlum et al. have developed a formal model in which entrepreneurs choose between becoming 'producers' or 'grabbers'. The relative payoff from these activities depends on how 'grabber-friendly' or 'producer-friendly' the institutions are, which also determines the effect of natural resources on the economy. This third

\footnotetext{
${ }^{6}$ Humphreys et al. (2007, p. 6) summarize three sources of income volatility: "the variation over time in rates of extraction, the variability in the timing of payments by corporations to states, and fluctuations in the value of the natural resource produced." A fourth source of volatility is international lending that follows oil "boom-bust cycles" (Ibid, p. 8).

${ }^{7}$ Oil can serve as collateral, or at least as an informal guarantee, since "the oil earnings are easy to identify and direct toward debt servicing." (Humphreys et al. 2007, p. 8).
} 
strand of literature correctly emphasizes on both technical and institutional appropriability. But how are these two elements of appropriability understood?

Boschini et al. (2007, p. 595) define the technical appropriability of any resource by reference to their physical and economical characteristics. "Resources which are very valuable, can be stored, are easily transported (or smuggled) and are easily sold are, for obvious reasons, more attractive to anyone interested in short-term illegitimate gains. This suggests that resources such as diamonds or precious metals are potentially more problematic than, say, agricultural products." While the concept of technical appropriability is germane to classifying different types of natural resources, the suggested definition suffers from a confusion between 'mobility' and 'appropriability'. What the authors call 'technical appropriability' is the same as 'lootability', since it pertains to "shortterm illegitimate gains" relating to alluvial (and not Kimberlite) diamonds or precious metals. In other words, the definition captures lootability of resources by bandits, rebels, and thieves rather than states. For example, oil is not easily transportable and should be classified as technically inappropriable according to the authors' definition despite its appropriability by a state. Moreover, following the resource curse literature, 'agricultural products' are excluded. But why should tubers and roots be excluded from the authors' definition of appropriability by rebels and escapees? In my viewpoint, the authors conflate technical appropriability with technical mobility ${ }^{8}$.

A second dimension of appropriability is institutional appropriability: "The potential problem of having certain types of resources can be countered by having good institutions...institutional quality determines the institutional appropriability of a resource.” (Boschini et al., Ibid., p. 595). The issue of institutional appropriability is conflated with 'institutional quality' measured by empirical indicators concerning how democratic a country is. Polity from the Polity IV data set or sub-components of the Institutions measure as suggested by Kaufmann, Kraay and Zoido-Lobaton (2002) regarding 'a state of law' have been employed to gauge the quality of institutions (Ibid, $p$. 612). Contrary to this method of measuring institutional quality, Wiens (2014) argues that there is no systematic relationship between fiscal reliance on resource revenue and a country's level of democracy. Instead, he suggests that we should expect: "(1) resource dependence to be systematically related to a country's likelihood of establishing restrictive institutions; and (2) that this relationship is conditioned by the nature of a country's institutions prior to the onset of resource-dependence." (Wiens 2014, p. 212). Restrictive institutions are not necessarily democratic ones, but they control the power of rulers. Considering institutional path dependency, it is assumed that if rulers' power is restricted before fiscal reliance of the state on resource revenue, then the curse will not occur. But to what extent 'resource appropriability' is conditional on democratic or restrictive institutions? Consider the Shah's regime in Iran during the period of agrarian reform (1962-1971). While his personal autocracy was strengthened due to the 'White Revolution', the combination of agrarian reform and the increasing oil revenue led to capitalist development, economic diversification and economic growth (Katouzian 1978; Hooglund 1982). The military dictatorship under Pinochet was not particularly restricted either, but the Chilean economy experienced economic growth and diversification. To put it differently, while some predatory states hinder economic development, others enhance it. There may be an empirical association between the institutional quality and institutional appropriability under certain conditions, but that does not prove that there is a direct causal relationship between them. In my opinion, institutional appropriability is directly related to the nature of political competition and

\footnotetext{
${ }^{8}$ This difference will be substantiated in the next section.
} 
the backgrounds of political elites defining property rights and enforcement. This point is substantiated in a recent version of staple theory ${ }^{9}$ developed by Nugent and Robinson (2010).

Investigating institutional differences of the coffee exporting economies of Latin America, namely Costa Rica and Colombia on the one hand, and El Salvador and Guatemala, on the other, Nugent and Robinson show that the different forms the coffee economy took in the nineteenth century was critically determined by the legal environment conditioning access to land. These differences in legal environment were driven in their turn by differences in the nature of political competition and the backgrounds of political elites. According to them, the "proximate cause of the difference is that both Colombia and Costa Rica passed laws rather like the 1862 Homestead Act in the United States, protecting smallholders and allowing them to gain title to land. On the other hand, in El Salvador and Guatemala, the onset of the coffee boom induced a mass land grab by powerful political elites who took possession of both Indian and free land themselves and created large coffee plantations. Alongside such land grabs came extreme labor repression." (Nugent and Robinson 2010, p. 50). But why did the political elites in these countries choose different strategies in taking advantage of the nineteenth century coffee market? Two factors have been identified: 1 ) the size of the army; 2) the nature of elites.

While the army was rather tiny in Costa Rica and Colombia, it was much stronger in El Salvador and Guatemala. The first factor explains why in Costa Rica and Colombia, the state did not have the required coercive means to expropriate land and engage in systematic labor repression. By contrast, in El Salvador and Guatemala, the army was used to trap captive agricultural laborers in large plantations. Moreover, in Costa Rica and Colombia, the merchants formed the political elites whereas in El Salvador and Guatemala, the elites were primarily composed of landowners. Consequently, in Costa Rica and Colombia, the elites chose to control commercial activities by monopolizing finance, credit provision and exportation of the crop. The combination of a tiny army and merchant political elites led to a relative preference for smallholder production and protection of property rights in Costa Rica and Colombia. Contrary to these countries, in El Salvador and Guatemala, the combination of landowners as political elites and stronger militarization induced a relative preference for large plantations. The authors also explain the lack (presence) of forward and backward linkages in these two types of Latin American coffee exporting countries in terms of political competition and the nature of political elites. "There is a natural connection between the type of coercion that characterized the labor market in El Salvador and Guatemala and the refusal of the state to invest in education. Unlike physical capital, human capital is only productive if workers exert complementary effort. But in a labor market based on coercion, workers were unlikely to believe that they would receive any return from exerting effort. In consequence, it is unlikely that there would be much payoff to landowning elites for investing in schools or the human capital of their workers." (Nugent and Robinson 2010, p. 51). The authors provide a new version of Baldwin's bipolar economy in which the distinction between diffuse and

\footnotetext{
${ }^{9}$ Nugent and Robinson (2010, p. 47) explicitly refer to "the powerful set of ideas developed in the context of the 'staple thesis"'. But they consider that endowments are not fate and that "Contrary to the nascent literature in economic attempting to explain institutional differences, our research suggests that the equilibrium institutional structure is not uniquely determined by factor endowments and depends crucially on the nature of political cleavages and competition in society." (Ibid, p. 54).
} 
pointy resources are applied to the same product. Coffee is a diffuse resource in Costa Rica and Colombia, in contrast to El Salvador and Guatemala where it is a pointy resource. The explanatory factor is no more physical characteristics or geographical location of a product, but its institutional environment. Put differently, there is no 'good' and 'bad' resource; the same resource might be bad or good depending on the political competition and the nature of political elites.

Another interesting point of this recent version of pointy versus diffuse resources is that institutional appropriability is not linked to the presence or absence of democracy. The political regimes in Costa Rica and Colombia were neither democratic nor restrictive. Merchants like their landowner counterparts were predatory, but they contributed to a diffuse political economy instead of a pointy one. But did these differences in terms of political economies reflect themselves in the type of assets that have been developed? This issue has not been addressed by Nugent and Robinson (2010).

In fact, Nugent and Robinson are more focused on rulers than assets. But the investigation about political competition might be conducted on the basis of the way the strategies of political elites could influence the structure of mobile/immobile assets. Costa Rica and Colombia were not democratic countries but their merchant elites had a preference for mobile assets (merchant capital), whereas landowners in El Salvador and Guatemala enhanced immobile assets (landed property). The structure of assets can be studied exogenously or endogenously. The geographical or purely physical characteristics describe the type of assets as given exogenously, but the strategies of political elites affect the assets' structure endogenously. Nugent and Robinson contribute to an endogenous theory of assets' structure that explains how the mobility and appropriability of assets can be influenced by the political strategies of elites. This brings us to reexamine both technical and institutional determinants of mobility and appropriability.

\section{Determinants of mobility and appropriability}

As mentioned above, Boschini et al. (2007) conflate technical appropriability with 'lootability' or mobility. We need to scrutinize the technical and institutional dimensions of both mobility and appropriability.

The technical mobility refers to all the physical characteristics of assets that make them mobile or give them hidden qualities. Several factors influencing technical mobility have been identified in section 3. Institutional mobility refers to all the rights of action that make assets mobile. This includes 1) allegiance shift; 2) rights of free entry, exit and circulation. Allegiance shift alludes to the fact that "Exit is not always associated with a physical move: people can decide to choose a different protector. This has been a common occurrence throughout history, and lords have often competed in demanding payments for protection in almost the same territory (Lane 1958/1979; Volckart 2000a, b). Hence, even geographically attached people might be 'mobile' in the sense that they have an 'exit power' and can choose their provider of protection." (Vahabi, Ibid, p. 162). Mobility is also a consequence of extending the rights of action through institutional change. The abolition of feudalism and the agrarian reform is a salient illustration of institutional change that extended peasants' mobility. The institutional mobility of peasants deeply impacted the army's structure in its turn. The birth of mass army with the French revolution provides a good example. "In an economy with a peasant majority, soldiers often consist of peasant conscripts paying their 
tributes to the king or lord. On the abolition of feudalism, peasants acquire an exit option and the army has to be restructured... In the [French] ancien régime, the army was aristocratic. Soldiers as subjects had no rights; the nobility had all the rights. Given the higher exit option of liberated peasants from the yoke of feudalism, the army had to provide them voice so that they could find their place in a modernized, reformed army as citizens, not subjects." (Pietri et al. 2017, p. 270, brackets added).

Hence, physical characteristics of assets or their geographical location are not the unique determinants of mobility. Allegiance shift and institutional change extending the rights of action over assets endogenously determine the mobility of assets. Wiens (2014) notices this institutional dimension of mobility when he discusses bargains between rulers and constituents with respect to exit option. "To secure their support, rulers bargain with prospective supporters, offering policy concessions in exchange for the required support. To shed light on the structural conditions underwriting these bargains, Clark et al. (2013) present a game-theoretic treatment of Hirschman's (1970) 'Exit, Voice, and Loyalty' argument. Their model shows that a ruler is compelled to limit himself and provide public goods wherever two conditions are met. First, he depends on the cooperation of some group of citizens to consolidate and sustain his rule. Second, the citizens on whose cooperation the ruler depends have credible 'exit threats'; that is, they can withhold their support without making themselves worse off than they would be were they to cooperate and provide the ruler with revenue." (Wiens 2014, pp. 202-203)

Mobility or the prey's ability to escape should not be confused with appropriability or the predator's capability to capture the prey. In the staple theory and resource curse literature, the appropriability issue has been explored through pointy versus diffuse resources. Pointy resources in terms of geographical concentration are regarded as appropriable and diffuse ones as inappropriable. However, appropriability has also two dimensions: technical and institutional. According to Vahabi (2016b, pp. 162-164), four principal ${ }^{10}$ determinants are germane in rendering assets technically more or less appropriable:

(1) State accessibility of assets: State accessibility is dependent on the geo-political location of assets and on industrial and military technological progress in transportation, communication and strike zones.

(2) Concentration or dispersal of assets: More concentrated assets are more accessible and appropriable. Dispersion is the enemy of appropriation for two reasons: it increases invisibility, and it augments the costs of accessibility and measurement.

(3) Asset specificity: An asset is more vulnerable to theft and coercive appropriation when it is more generic, because it can be more easily redeployed without losing value. A more specialized asset is more difficult to appropriate because its redeployment will incur the loss of quasi-rents from specific investment.

\footnotetext{
10 There are many other secondary factors such as 'storability' or 'perishability' of assets, their 'vulnerability to disease', and their character as 'labor-intensive' or 'capital intensive' that impact the appropriability of assets (regarding the impact of these factors on crops see Scott 2009, pp. 202-204). However, Vahabi only focuses on primary factors influencing all types of assets (physical as well as pecuniary ones).
} 
(4) Asset measurability: Accountability and controllability are essential in administering and appropriating assets. The more generic an asset is, the less costly its measurement will be since generic assets are often more homogeneous. By contrast, the more specific an asset is, the costlier its measurement will be because of its idiosyncratic, nonhomogeneous profile.

The institutional appropriability is not synonymous with institutional quality ${ }^{11}$. Assuming predatory states in a multi-predatory environment, institutional appropriability depends on the structure of political competition at domestic, regional and international levels. Two major types of competition are predatory and price competition. The former is violent competition between states, and the latter is competition à la Tiebout among different political units (Pietri et al. 2017). As Nugent and Robinson (2010) underline, the nature of political competition is shaped by the army's size, and the backgrounds of political elites that comprise the dominant social coalition. To these factors, I would add international political relationships. The identity of the dominant social coalition is particularly important in explaining the source of state's revenue and its expenditures. Political elites can influence the structure of assets with regard to appropriability and mobility. What is the state's major source of revenue: taxes over productive activity or revenue from extractive resources such as oil? And in case of fiscal states, the question is whether the taxes are exacted over immobile assets such as landed property, or over mobile assets such as merchant, financial and industrial capital. Regarding the state's expenditure, three key areas should be distinguished: (1) tax capacity, (2) coercive capacity, and (3) social welfare (Snyder and Bhavnani 2005, p. 571). Different types of political regimes constrained or non-constrained by a finite time horizon like autocratic, semi-democratic, and democratic have different priorities in their expenditure (Ibid, p. 573). This study shifts the focus from rebels to rulers. In other words, while 'mobility' tackles the rebel's behavior, appropriability deals with the ruler's actions.

The resource curse literature often confuses mobility and appropriability, but in some cases authors implicitly acknowledge the difference between them in a technical sense. For example, Auty (2001b) and Le Billon (2001) underline a determinant of the technical mobility, namely the geopolitical location of resources with respect to a national capital to measure the relative advantage of rebels compared to the state in grabbing distant resources. On the other hand, they point out a determinant of technical appropriability, i.e. the pointiness or diffuseness of resources in terms of geographical concentration. The two distinctions are related to the special characteristics of resources and their mode of control and production: "the characteristics of control can define resources as proximate or distant while those of access can distinguish them as point or diffuse." (Le Billon 2012, p. 28).

Le Billon suggests a combination of both criteria to yield a fourfold typology of conflict: 1) pointsource resources proximate to the capital are not easily movable and are appropriable. Since they are easily controllable by the state, only coup d'états could change the regime. 2) point-source resources distant from the capital are appropriable but movable and not easily controllable by the state. Thus secession movements can grab these resources. 3) diffuse-resources proximate to the capital are hardly appropriable but are not movable. Since they are hardly controllable by the state, they generate rebellions and rioting. 4) diffuse-resources distant from the capital are hardly

\footnotetext{
${ }^{11}$ The conventional indicators for institutional quantity are not appropriate to measure the institutional appropriability. New indicators with regard to the army's size, elites' background, the type of state's revenue and spending, and its geopolitical position in international politics (among others) are warranted to capture the institutional appropriability.
} 
appropriable and are movable. Hence, they induce warlordism or autonomous political territories. Table 1 summarizes Le Billon's results.

Table 1: Resource Characteristics and Conflict Types

\begin{tabular}{|c|c|c|}
\hline Characteristics & Point & Diffuse \\
\hline Proximate & Coup d'état & Mass rebellion \\
\hline Distant & Secession & Warlordism \\
\hline
\end{tabular}

Source: le Billon (2012, p. 29) ${ }^{12}$

It is noteworthy that Le Billon's argument is not that oil or any other resource should be linked to conflicts in a deterministic fashion, but that the "characteristics of resource sectors provide a context for political mobilization as well as for the motivations, strategies and capabilities of belligerents." (Le Billon 2012, p. 29).

The valuable foresight of this fourfold typology in analyzing potential conflictual situations notwithstanding, it suffers from a major shortcoming: both distinctions are used to determine different forms of rebellion rather than to explore the predatory nature of the state. Consequently, the two criteria of mobility and appropriability are not explicitly distinguished with regard to the state's appropriative capacity. They are treated as geopolitical and geographical criteria of 'accessibility' and 'controllability'. Accordingly, the institutional dimension of mobility and appropriability is disregarded. Moreover, since the rebellion has been the focus of study, all other technical and institutional factors that can cast light on the frontiers of a predatory state have been overlooked.

Vahabi (2016a, b) develops an alternative approach by focusing on a positive theory of the predatory state based on mobility and appropriability criteria. According to his theory, the booty value of an asset ${ }^{13}$ should be distinguished from its economic value. While the economic value of an asset is its value in a voluntary (market) transaction, its booty value is the amount of value that can be transferred or allocated through coercive capture of the asset. For the state, what matters is the booty value of an asset. The booty value of an asset depends on its exit option determined by the benefits of appropriation and the costs of capture. Combining the two criteria of appropriability and mobility, assets can be classified according to their booty value for the state. An 'assetappropriating' perspective of the state is opposed to a 'public goods' approach: "Instead of focusing on private versus public, it is necessary to investigate assets as less or more easily captured. Considering the two criteria, appropriability and mobility, all assets may be regrouped into four major categories: (1) pure fugitive assets that satisfy both mobility and nonappropriability criteria; (2) mixed fugitive assets that satisfy the mobility criterion but are appropriable; (3) mixed captive assets that do not satisfy the mobility criterion but are nonappropriable; (4) pure captive assets that are both appropriable and unmovable. In reality, state space is not decided by goods and services that are non-excludable and non-rivalrous, but rather by pure captive assets." (Vahabi 2016b, p. 160)

\footnotetext{
${ }^{12}$ Le Billon (2001, p. 573) illustrates the same table with country examples for each case of conflictual situation. Le Billon (2012, pp. 28-42) acknowledges other relevant factors such as legality, transportability, obstructability and substantiates his fourfold categories.

13 This includes all type of goods such as agricultural products like cereals and famine goods; and is not limited to natural resources such as oil, narcotics, diamonds, or other gemstones.
} 
While pure fugitive assets (category 1) are out of the state space, and pure captive assets (category 4) belong to the state space, the 'mixed fugitive assets' as well as the 'mixed captive assets' (categories 2 and 3) are intermediary assets and have ambivalent positions with regard to the state space. They can become part of a state space or undertake political exit; everything depends on the outcomes of the bargains between the state and the owners of these assets.

The appropriative perspective of the state integrates the potential conflictual situations over resources in relation to their booty value or exit option. The afore-mentioned classification is applicable not only to natural resources but to all types of assets. In this sense, the literature on the resource curse might be regarded as a particular case of a general theory of the predatory state.

\section{Conclusion}

There is a vast literature and several surveys on the economic and political resource curse. However, these surveys often fail to capture two points:

1) They disregard the relationship between the resource curse literature and the staple theory and the staple trap. A probable explanation may be the importance of empirical econometric tests in the recent curse/blessing literature in contrast to the early formulations of staple thesis that were not supported by such empirical tests. However, the recent staple theory models are often backed by a battery of empirical tests and they are now often mixed with resource curse literature. Many econometricians, more sensitive to econometric techniques than theoretical framework, have not yet taken cognizance of the fact that their tests on diffuse versus pointy resources are rooted in the staple theory.

2) The appropriability issue has only been treated tangentially and has never been the focus of any survey. In this paper, I showed that the political resource curse literature had initially focused on the appropriability issue through the lens of 'looting' behavior of rebels and distinguished 'lootable' and 'unlootable' goods. However, lootability casts light on mobility of resources or resistance to appropriation rather than state appropriability. Our critical review points out that the political resource curse only focused on state behavior since the early 2000s. A new distinction between point-source and diffuse resources was suggested to capture the appropriability issue. Interestingly, this distinction had already been made by Baldwin (1956) and other advocates of the 'staple theory'. My contention is that the underpinning tenets of the resource curse literature on appropriation are directly borrowed from the staple theory.

The present work fills these two gaps and casts light on a few major issues. First of all, the resource curse approach is applied to underdeveloped and developing countries, whereas the staple theory addresses 'new' economies including Canada and the United States. Borrowing upon the staple theory regarding pointy versus diffuse resources challenges the limitations of the resource curse approach. Can't the resource curse be reinterpreted as a form of staple trap applicable to all countries? Similarly, why should resource curse be limited to a certain group of products and exclude ordinary agricultural goods such as cereals, tubers and roots? 
The second point is the relationship between technical and institutional dimensions of resources. While the staple theory underlines different types of economic linkages (forward, backward, demand, fiscal and industrial conflict), the resource curse/blessing approach insists on geopolitical and geographical aspects of resources. In both cases, the technical dimension (geographical or purely physical qualities) is assumed to be primary. Institutional dimensions of appropriability and mobility are either absent or play a secondary role in their explanations. An alternative approach gives pride of place to the institutional dimension: the same agricultural product such as cereals or coffee can be appropriable or not depending on the institutional structure.

The third point is to explore different determinants of technical and institutional mobility and appropriability. The institutional aspect of mobility includes 1) allegiance shift; 2) rights of free entry, exit and circulation. The size of the army, political competition and the nature of elites have been identified as the source of institutional appropriability.

Finally, the fourth is to document a confusion between state appropriability and lootability (mobility). This distinction is fundamental in developing a positive theory of the predatory state. Exploring the sources of conflictual activities according to the nature of resources, a strand of work has suggested a combination of two criteria, namely the controllability and accessibility of resources. The former is related to pointiness or diffuseness of resources; the latter to the geopolitical distance of resources from the capital. In this sense, controllability partially measures state appropriability and the accessibility gauges the lootability by rebels. While this classification is purported to examine the conditions of rebellion, it implicitly enhances an appropriative approach to the state. The resource curse/blessing literature could be an additional support to a general positive theory of the predatory state.

\section{References}

Acemoglu, D. (1995). Reward structures and the allocation of talent. European Economic Review, 39(1), 17-33.

Ahmadov, A. (2014). Oil, democracy, and context a meta-analysis. Comparative Political Studies, 47(9), 1238-1267.

Atkinson, G. \& Hamilton, K. (2003). Savings, growth and the resource curse hypothesis. World Development, 31(11), pp. 1793-1807.

Aslaksen, S. (2010). Oil and democracy: more than a cross-country correlation? Journal of Peace Research, 47(4), 421-31.

Atabaki, T. A centurial social history of labor in the Iranian oil industry. Part one: 1908-1951 (Forthcoming).

Auty, R. (1993). Sustaining development in the mineral economies: the resource curse thesis. London: Routledge.

Auty, R. (1997). Natural resource endowment, the state and development strategy. Journal of International Development, 9, 651-663. 
Auty, R. (2001a). Resource abundance and economic development. Oxford: Oxford University Press.

Auty, R. (2001b). The political economy of resource-driven growth. European Economic Review, 45, 839846.

Auty, R. (2004). Natural resources and civil strife: a two-stage process. Geopolitics, 9(1), 29-49.

Baland, J.M. \& Francois, P. (2000). Rent-seeking and resource booms. Journal of Development Economics, 61(2), 527-42.

Baldwin R. (1956). Patterns of development in newly settled regions. Manchester School of Economics and Social Studies, 24, 161-79.

Ballentine, K. \& Sherman, J. (2003). The political economy of armed conflict: beyond greed and grievance. Boulder, CO: Lynne Rienner; New York: International Peace Academy.

Bazzi, S. \& Blattman, Ch. (2014). Economic shocks and conflict: evidence from commodity prices. American Economic Journal: Macroeconomics, 6(4), 1-38.

Beck, T. (2011). Finance and oil: is there a resource curse in financial development? European Banking Center Discussion Paper, 004.

Besley, T. \& Persson, T. (2009). The Origins of State Capacity: Property Rights, Taxation, and Politics. American Economic Review, 99(4), 1218-1244.

Boschini, A., Pettersson, J., \& Roine, J. (2007). Resource Curse or Not: A Question of Appropriability. Scandinavian Journal of Economics, 109(3), 593-617.

Boulding, K. (1960). Conflict and defense, a general theory. New York, Evanston and London: Harper and Row Publishers.

Bulte, E., Damania, R., \& Deacon, R. (2005). Resource Intensity, Institutions, and Development. World Development, 33(7), 1029-44.

Busse M. \& Gröning S. (2013). The resource curse revisited: governance and natural resources. Public Choice, 154(1), 1-20.

Caves, R. (1963). 'Vent for surplus' models of trade and growth. In Baldwin R. et al. (eds.), Trade, Growth and the Balance of payments: Essays in Honor of Gottfried Haberler. Chicago and Amsterdam, 95-115.

Caves, R. (1971). Export-led growth and the new economic history. In Bhagwati, J.N. et al. (eds.), Trade, Balance of payments and Growth, 404-42.

Clark, W., Golder M., \& Golder S. (2013). Power and politics: insights from an exit, voice, and loyalty game, Manuscript, University of Michigan and Penn State University.

Collier, P. (2000). Doing well out of war: an economic perspective. In Berdal, M. and Malone, D. (Eds.), Greed and grievance: economic agendas in civil wars. Ottawa, Boulder, Colo: Lynne Rienner.

Collier, P. (2007). The bottom billion: why the poorest countries are failing and what can be done about it. New York: Oxford University Press.

Collier, P. (2009). Wars, guns and votes: democracy in dangerous places. New York: Harper Collins. 
Collier, P. \& Bannon, I. (2003). Natural resources and violent conflict: options and actions. World Bank.

Collier, P. \& Hoeffler, A. (1998). On the economic causes of civil war. Oxford Economic Papers, 50, 563573.

Collier, P. \& Hoeffler, A. (1999). Justice-seeking and loot-seeking in civil war. Washington DC: World Bank.

Collier, P. \& Hoeffler, A. (2004). Greed and grievance in civil war. Oxford Economic Papers, 56(4), 563596.

Collier, P., Hoeffler, A., \& Söderbom, M. (2006). Post-conflict risks, centre for the study of African economies. Department of Economics, University of Oxford.

Cooter R. \& Ulen, T. (2012). Law and Economics (6th ed.). Boston: Addison-Wesley.

Cramer, Ch. (2002). Homo economicus goes to war: methodological individualism, rational choice and the political economy of war. World Development, 30(11), 1845-1864.

Cuaresma, J., Oberhofer, H., \& Raschky, P. (2011). Oil and the duration of dictatorships. Public Choice, 148(3/4), 505-530.

Deacon, R. (2011). The political economy of the natural resource curse: a survey of theory and evidence. Foundations and Trends (R) in Microeconomics, 7(2), 111-208.

Deacon, R., \& Rode, A. (2015). Rent seeking and the resource curse. Companion to the Political Economy of Rent Seeking, 227(14), 227-247.

Demsetz, H. (1964). The exchange and enforcement of property rights. Journal of Law and Economics, 7 , $11-26$.

Dunning, T. (2008). Crude democracy: natural resource wealth and political regimes. New York: Cambridge University Press.

Elbadawi, I. \& Sambanis, N. (2002). How much war will we see? Explaining the prevalence of civil war. Journal of Conflict Resolution, 46(3), 307-334.

Engerman, S. \& Sokoloff, K. (1997). Factor endowments, institutions, and differential paths of growth among new world economics, a view from economic historians of the United States. In Haber, S. (ed.), How Latin America fell behind, essays on the economic histories of Brazil and Mexico 1800-1914. Stanford, California: Stanford University Press, 260-297 (Chapter 10).

Fearon, J. \& Laitin, D. (1999). Weak states, rough terrain, and large-scale ethnic violence since 1943, paper presented at the annual meeting of the American Political Science Association, September 2-3, Atlanta, GA.

Fearon, J. \& Laitin, D. (2003). Ethnicity, insurgency, and civil war. American Political Science Review, 97(1), 75-90.

Frankel, J. (2010). The Natural Resource Curse: A Survey, Working Paper Mo. 15836, MA: National Bureau of Economic research.

Gelb, A. (1988). Oil windfalls: blessing or curse? New York: Oxford University Press. 
Goldberg, E., Wibbels, E., \& Myukiyehe, E. (2008). Lessons from strange cases: democracy, development, and the resource curse in the U.S. States. Comparative Political Studies, 41, 477-514.

Haber, S. \& Menaldo, V. (2011). Does oil fuel authoritarianism? A reevaluation of the resource curse. American Political Science Review, 105(1), 1-26.

Harewell, E., Farah, D. \& Blundell, A. (2011). Forests, fragility, and conflict: overview and case studies. Washington D.C.: Program on Forest.

Hegre, H. (2002). Some social requisites of a democratic civil peace: democracy, development, and armed conflict, paper presented to the Annual Meeting of the American Political Science Association, Boston, MA, 29 August-1 September, http://econ.worldbank.org/files/18170 DDCWAPSA2002.PDF

Herb, M. (2005). No representation without taxation? Rents, development, and democracy. Comparative Politics, 37(3), 297-316.

Hirschman, A. (1958). The Strategy of economic development. New haven: Yale University Press.

Hirschman, A. (1977). A generalized linkage approach to development, with special reference to staples. Economic Development and Cultural Change, 25, 67-98.

Hodler, R. (2006). The curse of natural resources in fractionalized countries. European Economic Review, 50(6), 1367-1386.

Hooglund, E. (1982). Land and revolution in Iran 1960-1980. Austin: University of Texas Press.

Humphreys, M. (2005). Natural resources, conflict and conflict resolution. Journal of Conflict Resolution, 49, 508-37.

Humphreys, M., Sachs J., \& Stiglitz J. (2007). Introduction: what is the problem with natural resource wealth? In Humphreys, M., Sachs, J., \& Stiglitz, J. (Eds.). Escaping the resource curse. New York: Columbia University Press.

Innis, H. (1930/1956). The fur trade in Canada: an introduction to Canadian economic history. Toronto, $2^{\text {nd }}$ edition.

Innis, H. (1940/1954). The cod fisheries: the history of an international economy. Toronto, $2^{\text {nd }}$ edition.

Isham, J., Woolcock, M., Prichett, L. \& Busby G. (2005). The varieties of resource experience: how natural resource export structures affect the political economy of economic growth. World Bank Economic Review, 19(2), 141-174.

Jensen, N. \& Wantchekon, L. (2004). Resource wealth and political regimes in Africa. Comparative Political Studies, 37, 816-41.

Karl, T. (1997). The paradox of plenty: oil booms and petro-states. Berkeley: University of California Press.

Kaufmann, D., Kraay, A. \& Zoido-Lobaton, P. (2002). Governance matters II-updated indicators 2000/01. World Bank Policy Research Working Paper no. 2772, Washington, DC.

Katouzian, M. (1978). Oil versus agriculture: a case of dual resource depletion in Iran. The Journal of Peasant Studies, 5(3), 347-369. 
Keen, D. (1994). The benefits of famine: a political economy of famine and relief in Southwestern Sudan, 1983-1989. Princeton N.J.: Princeton University Press.

Keen, D. (1998). The economic functions of violence in civil wars. Oxford, New York: Oxford University Press for the Institute for Strategic Studies.

Keen, D. (2005). Conflict and collusion in Sierra Leone. Oxford: James Currey.

Keen, D. (2012). Greed and grievance in civil war. International Affairs, 88(4), 757-777.

Kindleberger, C. (1958). Economic development. N.Y., Toronto, London: The McGraw book.

Lane, F., (1958/1979). Economic consequences of organized violence. In Profit from Power, New York: State University of New York, 50-65.

Lane P. \& Tornell A. (1996). Power, growth, and the voracity effect. Journal of Economic Growth, 1, 21341.

Lane P. \& Tornell A. (1999). The voracity effect. American Economic Review, 89, 22-46.

Le Billon, P. (2001). The political ecology of war: natural resources and armed conflicts. Political Geography, 20(5), 561-584.

Le Billon, P. (2012). Wars of plunder, conflicts, profits and the politics of resources. London: Hurst \& Company.

Leeson, P. (2007). Trading with bandit. Journal of Law and Economics, 50(2), 303-321.

Leite C. \& Weidmann J. (2002). Does Mother Nature corrupt?-natural resources, corruption, and economic growth. In Abed, G. \& Gupta, S. (Eds.). Governance, corruption, and economic performance, Washington, DC, International Monetary Fund, 156-169.

Mackintosh, W. (1923). Economic factors in Canadian history. Canadian Historical Review, IV, 12-25.

Mackintosh W. (1936). Some aspects of a pioneer economy. The Canadian Journal of Economics and Political Science, II, 457-63.

Mahdavy, H. (1970). The patterns and problems of economic development in rentier states: the case of Iran. In Cook, M. (ed.), Studies in economic history of the Middle East. London: Oxford University Press, 42867.

Mann, M. (2005). The dark side of democracy: explaining ethnic cleansing. New York: Cambridge University Press.

Matsuyama, K. (1992). Agricultural productivity, comparative advantage, and economic growth. Journal of Economic Theory, 110(3), 681-712.

Mayshar, J., Moav O., Neeman Z., \& Pascali L. (2015). Cereals, appropriability and hierarchy. Centre for Economic Policy Research, No. 10742, Development Economics, Economic History, Macroeconomic and Growth and Public Economics, August.

McNeill, W. (2007). Frederick the Great and the propagation of potatoes. In Hollinshead, B. \& Rabb, T. (Eds.). I wish I'd been there: twenty historians revisit key moments in history, London: Macmillan, 176189. 
McGuirk, E. (2013). The illusory leader: natural resources, taxation and accountability. Public Choice, 154, 285-313.

Mehlum, H., Moene, K. \& Torvik, R. (2006). Institutions and the resource curse. Economic Journal, 116, $1-20$.

Menaldo, V. (2016). The institutions curse, natural resources, politics, and development. Cambridge: Cambridge University Press.

Mitchell, T. (2011). Carbon democracy: political power in the age of oil. London: Verso.

Morrison K. (2007). Natural resources, aid, and democratization: a best-case scenario. Public Choice, 131(3/4), 365-386.

Neary, P. \& van Wijnbergen, S. (Eds.) (1986). Natural resources and macroeconomy. Cambridge, Mass.: MIT Press; Oxford: Blackwell.

North, D. (1955). Location theory and regional economic growth. Journal of Political Economy, 63(3), 243-258.

North, D. (1956). International capital flows and the development of the American West. The Journal of Economic History, 16(4), 493-505.

North, D. (1958). A note on Professor Rostow's "Take-off" into self-sustained economic growth". Manchester School of Economic and Social Studies, 26, 68-75.

North, D. (1959). Agriculture in regional economic growth. Journal of Farm Economics, 41(5), Proceedings of the Annual Meeting of the American Farm Economic Association, Dec, 943-951.

North, D. (1981). Structure and change in economic history. New York, London: W.W. Norton and Company.

North, D., Wallis J., \& Weingast, B. (2009). Violence and social orders: A conceptual framework for interpreting recorded human history. New York: Cambridge University Press.

North, D., Wallis, J., Webb, S., \& Weingast, B. (eds.) (2013). In the Shadow of Violence, Politics, Economics, and the Problems of Development. Cambridge: Cambridge University Press.

Nugent, J. \& Robinson, J. (2010). Are factor endowments fate? Revista de Historia Economica/Journal of Iberian and Latin American Economic History, 28, 45-82.

Nunn, N. \& Qian, N. (2011), The potato's contribution to population and urbanization: evidence from a historical experiment, Quarterly Journal of Economics, 126, 593-650.

Papaioannou, E. \& Gregorios, S. (2008). Economic and social factors driving the third wave of democratization, Journal of Comparative Economics, 36, 365-87.

Perloff, H. \& Lowdon W. (1961). Natural resource endowment and regional economic growth. In Spengler, J., (ed.). Natural Resources and Economic Growth, Washington, pp. 191-212.

Pietri, A. and Tazdait, T. \& Vahabi, M. (2017). Economics of empire-building: price and predatory competitions. Journal of Institutional and Theoretical Economics, 173(2), 253-278. 
Price, S. (2003). War and tropical forests. Binghamton, New York: Food Products Press.

Ramsay, K. (2011). Revisiting the resource curse: natural disasters, the price of oil, and democracy. International Organization, 65(3), 507-529.

Reno, W. (1997). Humanitarian emergencies and warlord economies in Liberia and Sierra Leone. Helsinki, Finland: UNU World Institute for Development Economic Research.

Ross, M. (1999). The political economy of the resource curse. World Politics, 51, 297-322.

Ross, M. (2001). Does oil hinder democracy? World Politics, 53, 325-361.

Ross M. (2003). Oil, drugs, and diamonds: the varying roles of natural resources in civil war. In Ballentine, K. \& Sherman, J. (Eds.). The political economy of armed conflict, beyond greed \& grievance. Boulder, Colorado: Lynne Reinner Publishers, Inc., 47-72.

Ross, M. (2004). What do we know about natural resources and civil war? Journal of Peace Research, Vol. 41(3), 337-356.

Ross, M. (2009). Oil and democracy revisited, University of California-Los Angeles, Mimeo.

Ross, M. (2012). The oil curse: how petroleum wealth shapes the development of nations. Princeton: Princeton University Press.

Ross, M. (2014), What have we learned about the resource curse? February 12, 2014.

Sachs, J., \& Warner, A. (1995). Natural resource abundance and economic growth, Development Discussion Paper 517a. Cambridge, MA: Harvard Institute for International Development.

Sachs, J., \& Warner, A. (2001). The curse of natural resources. European Economic Review, 45(4), 827838.

Salai-I-Martin, X. \& Subramanian, A. (2003). Addressing the natural resource curse: an illustration from Nigeria, Working paper 9804, NBER, Cambridge.

Schedvin, C. (1990). Staples and regions of Pax Britannica. The Economic History Review, 43(4), 533-559.

Scott, J. (2009). The art of not being governed, an Anarchist history of Upland Southeast Asia. New Haven \& London: Yale University Press.

Shafer, D. (1994). Winners and Losers, how sectors shape the developmental prospects of states. Ithaca and London: Cornell University Press.

Smith, B. (2007). Hard times in the land of plenty: oil politics in Iran and Indonesia. Ithaca, N.Y.: Cornell University Press.

Snyder, R. \& Bhavnani, R. (2005). Diamonds, blood, and taxes: A revenue-centred framework for explaining political order. Journal of Conflict Resolution, 49(4), 563-597.

Snyder, R. (2006). Does lootable wealth breed disorder? A political economy of extraction framework. Comparative Political Studies, 39(8), 943-968.

Sokoloff, K. and Engerman, S. (2000). History lessons: institutions, factors endowments, and paths of development in the New World. Journal of Economic perspectives, 14(3), 217-232. 
Sorens, J. (2011). Mineral production, territory, and ethnic rebellion: the role of rebel constituencies. Journal of Peace Research, 48(5), 571-585.

Stewart, F., FitzGerald, V. \& associates, (Eds.) (2001). War and underdevelopment: the economic and social consequences of conflict, Vol. 1, Oxford: Oxford University Press.

Stewart, F., Brown, G., \& Langer, A. (2008). Major findings and conclusions on the relationship between horizontal inequalities and conflict. In Stewart, F. (ed.). Horizontal inequalities and conflict: understanding group violence in multiethnic societies. New York: Palgrave Macmillan.

Tornell, A., \& Lane, P. R. (1999). The voracity effect. The American Economic Review, 89(1), 22-46.

Torvik, R. (2001). Learning by doing and the Dutch disease. European Economic Review, 45, 285-306.

Torvik, R. (2002). Natural resources, rent seeking and welfare. Journal of Development Economics, 67, 455-470.

Vahabi, M. (2016a). The political economy of predation: manhunting and the economics of escape. New York: Cambridge University Press.

Vahabi, M. (2016b). A Positive theory of the predatory state. Public Choice, 168(3-4), 153-175.

Van der Ploeg, F. (2011). Natural resources: curse or blessing? Journal of Economic Literature, 49(2), 366420.

Volckart, O. (2000a). The open constitution and its enemies: competition, rent Seeking, and the rise of the modern state. Journal of Economic Behavior and Organization, 42, 1-17.

Volckart, O. (2000b). State building by bargaining for monopoly rents. Kyklos, 53(3), 265-293.

Wantchekon, L. (2002). Why do resource dependent countries have authoritarian governments? Journal of African Finance and Economic Development, 2, 57-77.

Watkins, M. (1963). A staple theory of economic growth. The Canadian Journal of Economics and Political Science, 29(2), 141-158.

Wick, K. \& Bulte, E. (2006). Contesting resources-rent seeking, conflict and the natural resource curse. Public Choice, 128, 457-476.

Wick K. \& Bulte, E. (2009). The curse of natural resources. Annual Review of Resource Economics, 1, 139156.

Wiens, D. (2014). Natural resources and institutional development. Theoretical Politics, 26(2), 197-221.

Woolcook, M., Pritchett, L. \& Isham, J. (2001). The social foundations of poor economic growth in resource rich economies. In Auty R. (ed.), Resource Abundance and Economic Development. New York: Oxford University Press.

Wright, G. (2001). Resource-based growth then and now, prepared for the World Bank Project Patterns of Integration in the Global Economy, Stanford University. 